\title{
Extracellular Polysaccharides from Xanthomonas axonopodis pv. manihotis Interact with Cassava Cell Walls During Pathogenesis
}

\author{
B. Boher, M. Nicole, M. Potin, and J. P. Geiger \\ ORSTOM, Laboratoire de Phytopathologie, BP 5045, 34032 Montpellier, France \\ Received 7 April 1997. Accepted 9 July 1997.
}

The location of lipopolysaccharides produced by Xanthomonas axonopodis pv. manihotis during pathogenesis on cassava (Manihot esculenta) was determined by fluorescence and electron microscopy immunolabeling with monoclonal antibodies. During the early stages of infection, pathogen lipopolysaccharides were detected on the outer surface of the bacterial envelope and in areas of the plant middle lamellae in the vicinity of the pathogen. Later in the infection process, lipopolysaccharide-specific antibodies bound to areas where the plant cell wall was heavily degraded. Lipopolysaccharides were not detected in the fibrillar matrix filling intercellular spaces of infected cassava leaves. Monoclonal antibodies specific for the exopolysaccharide xanthan side chain labeled the bacteria, the fibrillar matrix, and portions of the host cell wall. The association of Xanthomonas lipopolysaccharides with host cell walls during plant infection is consistent with a role of these bacterial extracellular polysaccharides in the infection process.

Additional keywords: electron microscope, immunodetection.

Bacterial surface polysaccharides occur mainly in two forms; lipopolysaccharides (LPS) anchored to the cell surface by the lipid A moiety, and exopolysaccharides (EPS) released as an extracellular slime. LPS and EPS produced by gramnegative bacteria are known to play important roles in pathogenic interactions with plants. In this respect, transposon mutagenesis on genes governing exopolysaccharide synthesis of Erwinia amylovora, E. stewartii, or Xanthomonas campestris pv. citrumelo resulted in delaying symptom expression (Denny 1995).

In the course of the parasitic process, EPS contribute to host tissue invasion by and dissemination of E. amylovora (Schouten 1989) or plant wilting during infection by Clavibacter michiganense subsp. insidiosum (Van Alfen et al. 1987) or X. oryzae pv. oryzae (Vidhyasekaran et al. 1989). The hydrophilic polysaccharides create an environment favoring the pathogen growth in planta and could act as a protective barrier against toxic compounds from host origin (Leigh and Coplin 1992). LPS may account for plant-bacterium recognition processes such as those occurring in plant/Agrobacterium

Corresponding author: B. Boher; Telephone: 3304674162 91; Fax: 33 674162 83; E-mail: boher@mpl.orstom.fr
(Whatley et al. 1976) or plant/Pseudomonas (Zamze et al. 1985) interactions. Purified LPS extracted from phytopathogenic Pseudomonads can prevent hypersensitive necrosis (Mazzuchi and Pupillo 1976; Mazzuchi et al. 1979). The Oantigenic side chain of the LPS of P. fluorescens has been implicated in the induction of disease resistance by this microorganism (Leeman et al. 1995) and recently Duijff and coworkers (1997) assessed involvement of this O-antigenic chain in endophytic root colonization by the bacteria. LPS from $X$. campestris induced defense-related gene expression in Brassica campestris (Newman et al. 1995). Dow et al. (1995) described a pathogenicity locus of $X$. campestris involved in biosynthesis of an LPS core component and reported that intact LPS was required for full virulence on a range of plants.

Ultrastructural investigation on bacterial extracellular polysaccharides during plant-microbe interactions has provided accurate information on their association with plant cell structures. Using anti-xanthan polyclonal antibodies, Watabe et al. (1993) showed that EPS were localized in areas close to the cells of $X$. oryzae pv. oryzae in rice. Brown et al. (1993 and 1995) used immunocytochemistry to localize EPS produced by $X$. campestris pv. vesicatoria. EPS were detected in and around bacteria cells, and also in the intercellular spaces of pepper tissues filled with a fibrillar matrix. The authors suggested a possible role for EPS in signal exchange during the incompatible interaction. A similar labeling pattern was obtained in cassava tissues colonized by $X$. axonopodis pv. manihotis (Xam) (Boher et al. 1995). These authors also investigated the association of Xam EPS with plant cell walls during bacterial ingress into cassava vascular elements; they suggested that Xam EPS may be associated with host cell wall alteration (Boher et al. 1996). Robinson (cited by Hodson et al. 1995) reported the presence of LPS from X. campestris ahead of invading organism in the plant tissues, indicating that bacterial cell wall components can be released during infection.

In light of these observations, bacterial extracellular polysaccharides can potentially interact with the plant cell wall during invasion of host tissues. In the present study, we have used immunocytochemical analysis to determine the localization of bacterial extracellular polysaccharide epitopes during cassava leaf colonization by Xam. Immunochemical evidence of LPS accumulation in plant cell walls is presented, suggesting a close interaction between these compounds and plant polysaccharides during pathogenesis. 


\section{RESULTS}

\section{Electrophoresis and Western blotting of bacterial extracellular polysaccharides.}

Silver-stained profiles obtained after electrophoresis of extracts of strain X27 (Fig. 1, lane 1) displayed a bimodal pattern typical of purified LPS extracts of Xanthomonas (Benedict et al. 1990; Ojanen et al. 1993) and other genera of plant-pathogenic bacteria (Hendrick and Sequeira 1984; Ovod et al. 1995; Schoonejans et al. 1987; Siverio et al. 1993). A ladder-like pattern was visible in the low molecular area of the gel (Fig. 1, lane 1, A) corresponding to smooth LPS (containing $\mathrm{O}$ chain), with the faster-moving molecules (Fig. 1, lane 1, B) representing rough LPS (core). The smooth LPS of Xam X27 lacks high molecular components as described for purified LPS of $X$. campestris pv. vesicatoria or X. campestris pv. translucens (Ojanen et al. 1993). The avirulent isolate ORST4 presented a distinct pattern (Fig. 1, lane 2) with only fast-moving bands. The monoclonal antibody (MAb) BOR9H8 reacted only with slow-migrating molecules, giving the typical banding pattern of smooth LPS in Western blots (immunoblots) (Fig. 1, lane 3). Two regions of binding (Fig. 1, lane 3, a and b) were observed, as previously described by Benedict et al. (1990) for MAbs Xbeg-1 and Xpel-1 reacting with purified LPS of $X$. campestris pv. pelargonii. After protease (Fig. 1, lane 4) or lyzozyme (Fig. 1, lane 5) treatment, the same profile was observed. Blots incubated with the antixanthan B3 (data not shown) yielded negative results.

\section{Occurrence of BOR9H8 and B3 epitopes in Xanthomonas pathovars.}

Cross-reactivity of BOR9H8 and B3 MAbs with Xanthomonas pathovars was assessed with immunofluorescence microscopy (Table 1). While cross-reaction of B3 MAb was observed with all tested pathovars, BOR9H8 MAb reacted with only 48 of 57 tested isolates of Xam and the isolates of pvs.

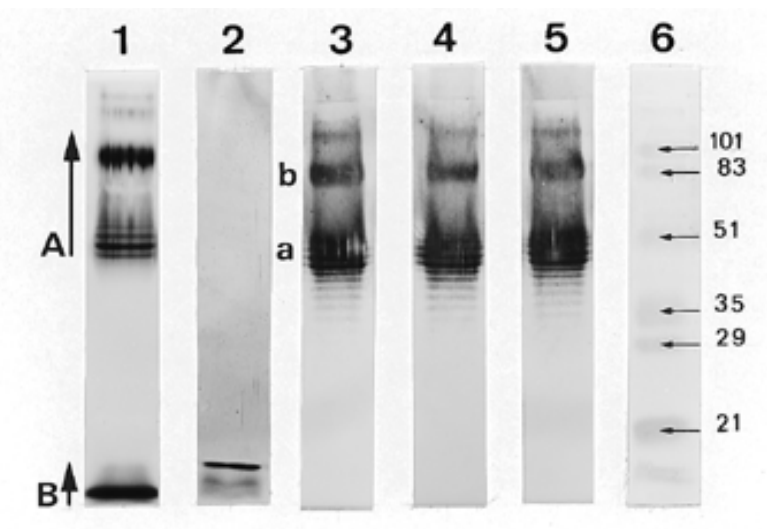

Fig. 1. Sodium dodecyl sulfate analysis and immunoblotting of polysaccharides extracted from Xanthomonas axonopodis pv. manihotis isolates X27 and ORST4. Silver-stained profile of polysaccharides extracted from cells of isolate X27 (lane 1) and the avirulent isolate ORST4 (lane 2). Immunoblot of polysaccharides extracted from isolate $X 27$ reacted with monoclonal antibody BOR9H8 (dilution 1/32) as observed after treatment with goat anti-mouse antibody conjugated to alkaline phosphatase and nitro blue tetrazolium substrate (lane 3). Lane 4, same as lane 3 but treated with proteinase. Lane 5, same as lane 3 but treated. with lysozyme. Lane 6, pre-stained standard proteins (161-0305, BioRad, Hercules, CA). citri, euphorbiae, and vasculorum. No correlation could be made between Xam pathogenicity and BOR9H8 MAb crossreactivity.

\section{Immunocytochemical detection of bacterial extracellular polysaccharides during pathogenesis.}

Semi-thin sections from cassava leaves infected by Xam isolate X27 were treated first with B3 MAb then with goat anti-mouse antibody conjugated to fluorescein. Specific green fluorescence on these sections was associated with mesophyll intercellular spaces occupied by bacteria and the fibrillar matrix (Fig. 2A). In contrast, after incubation of sections with the primary BOR9H8 MAb, a strong fluorescence was seen over walls of bacteria located in intercellular spaces and sometimes over portions of host middle lamellae in infected areas only (Fig. 2B). Sections of healthy tissues treated either with BOR9H8 (Fig. 2C) or with B3 (data not shown) were devoid of the characteristic fluorescein isothiocyanate (FITC) green

Table 1. Cross-reactivity of BOR9H8 and B3 monoclonal antibodies (MAbs) with isolates of Xanthomonas pathovars, using immunofluorescence microscopy

\begin{tabular}{|c|c|c|c|c|}
\hline Pathovars and species & Isolates $^{\mathbf{a}}$ & $\begin{array}{l}\text { Path- } \\
\text { ogen- } \\
\text { icity }^{\text {b }}\end{array}$ & BOR9H8 $^{c}$ & $\mathbf{X B 3}^{\mathrm{c}}$ \\
\hline$X$. axonopodis pv. manihotis & LMG5287 & + & + & + \\
\hline$X$. axonopodis pv. manihotis & ORST34 & + & + & + \\
\hline$X$. axonopodis pv. manihotis & X27 & + & + & + \\
\hline$X$. axonopodis pv. manihotis & LMG5249 & + & - & + \\
\hline$X$. axonopodis pv. manihotis & ORST4 & - & - & + \\
\hline X. axonopodis pv. manihotis & UPB079 & - & - & + \\
\hline X. axonopodis pv. manihotis & UnB638 & - & + & + \\
\hline$X$. cassavae & UPB030 & + & - & + \\
\hline X. cassavae & UPB049 & + & - & + \\
\hline$X$. cassavae & NCPPB101 & - & - & + \\
\hline X. cassavae & UPB008 & - & - & + \\
\hline X. translucens pv. cerealis & UPB453 & - & - & + \\
\hline$X$. axonopodis pv. citri & CFBP1814 & - & + & + \\
\hline$X$. axonopodis pv. dieffenbachiae & NCPPB 1843 & - & - & + \\
\hline X. campestris pv. euphorbiae & LMG863 & - & + & + \\
\hline $\begin{array}{l}\text { X. translucens pv. translucens } \\
\text { (formerly, X. campestris pv. } \\
\text { hordei) }\end{array}$ & UPB458 & - & - & + \\
\hline$X$. axonopodis pv. incanae & CFBP1438 & - & - & + \\
\hline X. arboricola pv. juglandis & 11301 & - & - & + \\
\hline X. axonopodis pv. malvacearum & GAR1-2 & - & - & + \\
\hline $\begin{array}{l}X . \text { campestris pv. mangiferaein- } \\
\text { dicae }\end{array}$ & NCPPB 490 & - & - & + \\
\hline$X$. hortorum pv. pelargonii & NCPPB2985 & - & - & + \\
\hline$X$. axonopodis pv. phaseoli & CFBP1816 & - & - & + \\
\hline$X$. translucens pv. poae & UPB454 & - & - & + \\
\hline$X$. axonopodis pv. poinsetticola & UPB073 & - & - & + \\
\hline$X$. axonopodis pv. secalis & UPB469 & - & - & + \\
\hline X. translucens pv. translucens & UPB448 & - & - & + \\
\hline X. translucens pv. undulosa & UPB513 & - & - & + \\
\hline X. axonopodis pv. vasculorum & NCPPB796 & - & + & + \\
\hline X. vesicatoria & 10501 & - & - & + \\
\hline
\end{tabular}

a Origin of isolates: LMG, Laboratorium voor Microbiologie Gent, Culture Collection, Universiteit Gent, Belgium; NCPPB, National Collection of Plant Pathogenic Bacteria, Harpenden, U.K.; ORST, Xanthomonas Collection, Laboratoire de Phytopathologie, Montpellier, France; UPB, Collection of H. Maraite, Louvain la Neuve, Belgium; UnB, Collection of A. Takatsu, Universidade de Brasilia, Brazil; GAR1-2, isolate from Cameroun (J. F. Daniel, this laboratory); X27, isolate from Togo (B. Boher, this laboratory); 10501 and 11301, Collection Française de Bactéries Phytopathogènes, Angers, France.

$\mathrm{b}+=$ pathogenic on cassava; $-=$ nonpathogenic on cassava

$c+/-=$ presence or absence of specific green fluorescence. 
fluorescence. The same negative result was obtained when sections were treated by periodate before reacting with BOR9H8 (data not shown). On the other hand, when crude LPS from Xam were infiltrated into cassava leaflets, green fluorescence associated with the BOR9H8 epitope was detected on walls of some cells (data not shown).

Immunoelectron microscopic observations of thin sections confirmed these data. After incubation with the MAb B3 followed by treatment with goat anti-mouse conjugated to colloidal gold, labeling was seen over the fibrillar sheath and the bacteria present in mesophyll intercellular spaces colonized by Xam isolate X27 (Fig. 3A). Portions of host cell walls associated with the bacterial EPS were also decorated with gold (Fig. 3B); no other host cell structures were labeled. Sections treated with the BOR9H8 MAb showed that the targeted epitope was mainly located on the external surface of the bacterial wall (Fig. 3C). The fibrillar sheath present in the infected intercellular spaces was not labeled by this antibody (compare Fig. 3A and C). A similar pattern of labeling occurred over degenerated bacteria seen in vascular tissues (Fig. 3D).

At the boundary of disease progress in the leaf parenchyma tissue, the BOR9H8 epitope was detected in restricted portions of the middle lamellae, as judged by the distribution of gold particles at these sites (Fig. 3E). This presence of the BOR9H8 epitope in the apoplast was detected only in the immediate vicinity of bacteria. In tissues where bacterial colonization led to severe alterations of host cell walls and middle lamellae (Figs. 3F, 4A), a strong labeling was seen over degraded areas while the fibrillar sheath in the intercellular spaces remained unlabeled. A similar labeling pattern was observed in colonized intercellular spaces of infected stem tissues (not illustrated).

In contrast, when cassava leaves were infected with isolate UPB049 of X. cassavae, a necrogenic pathogen of cassava, no significant gold decoration was observed after treatment of sections with the BOR9H8 MAb; neither the bacterial cells nor degraded host wall structures were labeled (Fig. 4B). Treatment of sections from noninfected tissues from cassava with either the B3 or BOR9H8 MAbs did not cause any significant labeling (data not shown).

Controls including incubation of sections with (i) the antibody to which the corresponding antigenic molecule was previously added, (ii) preimmune mouse serum instead of the primary antiserum, and (iii) omission of the primary antibody incubation step, yielded negative results (data not shown). When sections were incubated with the BOR9H8 MAb to which plant cell wall compounds were previously added, the labeling pattern was not altered, compared with that described before (not shown).

\section{Cytolocalization of plant cell wall pectin and $\beta$-1,4-glucans.}

An even distribution of label was observed on the degraded middle lamellae of Xam-infected leaf cells after incubation of section with the JIM5 antipectin MAb followed by goat antirat-gold antibodies (Fig. 4C). Few or no gold particles were seen over the bacterial extracellular polysaccharides and the bacterial cells. When $\beta$-1,4-glucans were detected by means
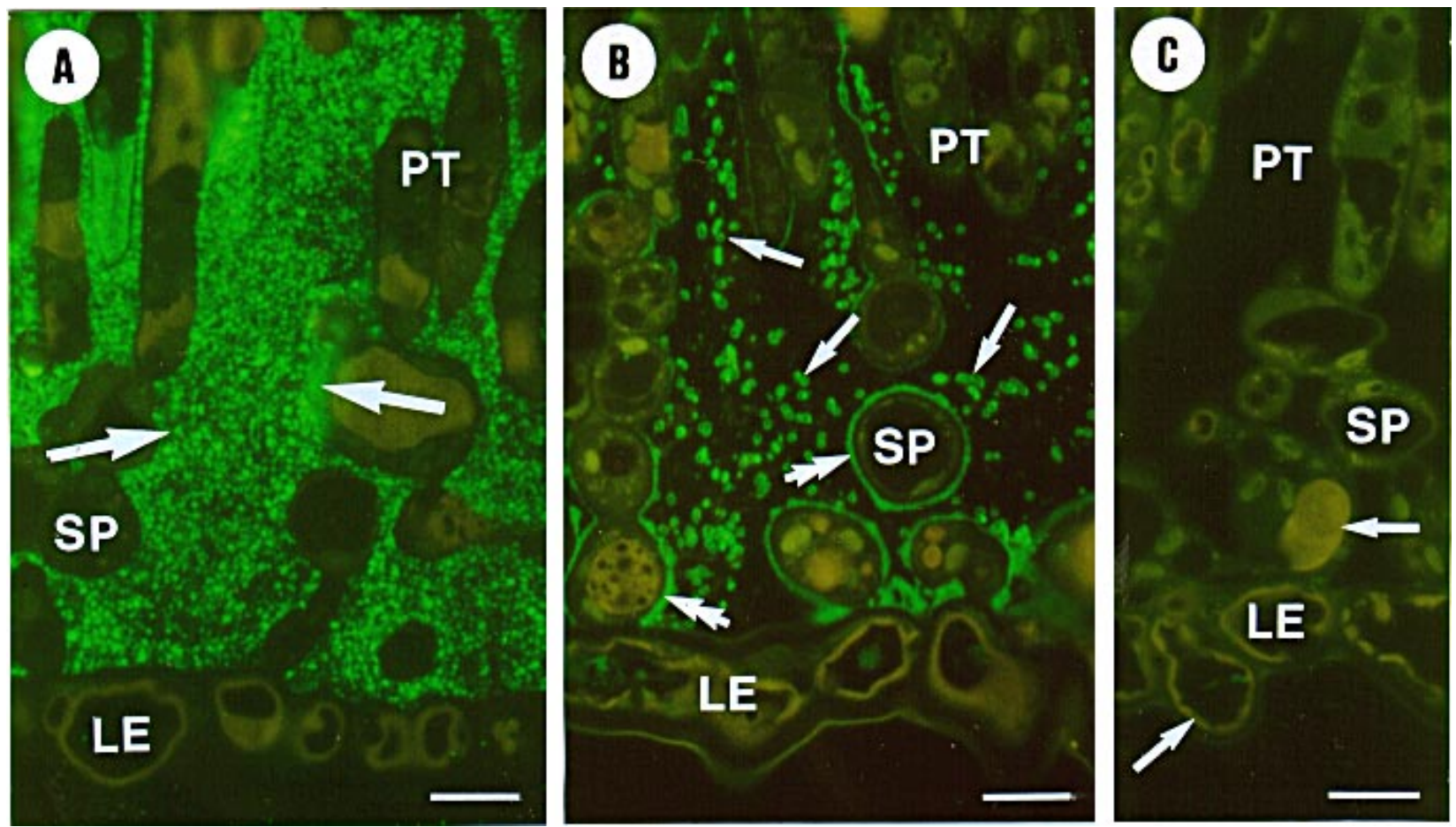

Fig. 2. Immunohistochemical localization of B3 monoclonal antibody (MAb) epitope (A) and BOR9H8 MAb epitope (B) in mesophyll of cassava 7 days after infection by Xam X27 isolate (aldehyde fixed, immunofluorescence). A, Sections from infected cassava mesophyll treated with B3 MAb show that the green fluorescence is visible in the intercellular spaces occupied by the pathogen and exopolysaccharides (arrows). B, Sections from infected cassava mesophyll incubated with BOR9H8 MAb show the green fluorescence over the outer layer of the bacterial cells (arrows) and on portions of the host middle lamella close to infected intercellular spaces (double arrows). Other host-cell components and bacterial exopolysaccharides are not fluorescent. C, Sections from healthy cassava mesophyll treated with BOR9H8 MAb show no fluorescence except yellow autofluorescence of epidermal or mesophyll cells (arrows). Bar $=12 \mu \mathrm{m}$. LE, lower epidermis; PT, palisade tissue; SP, spongy parenchyma. 

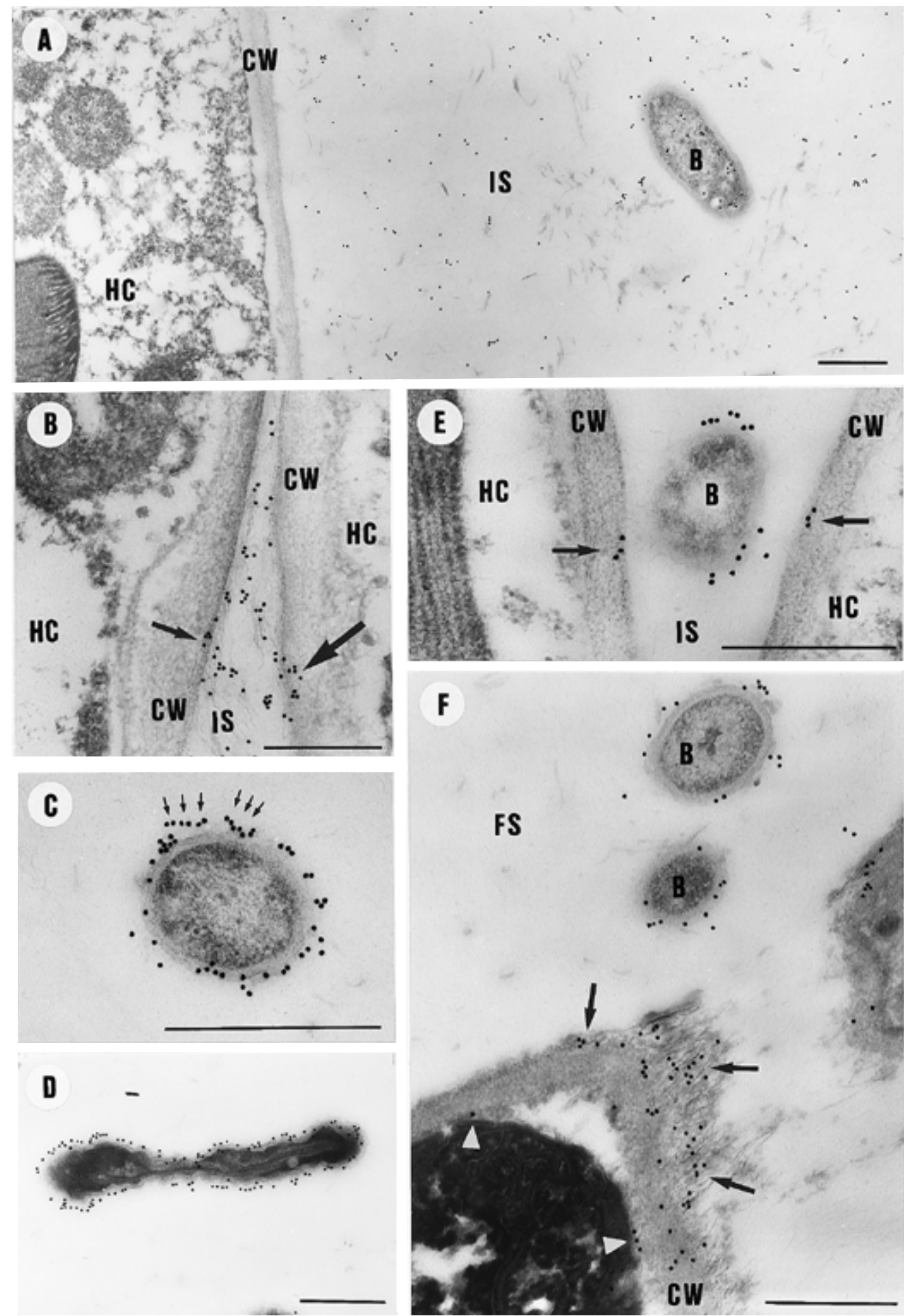

Fig. 3. Immunocytochemical localization of B3 monoclonal antibody (MAb) epitope (A, B) and BOR9H8 MAb epitope $(\mathbf{C}, \mathbf{D}, \mathbf{E}, \mathbf{F})$ in mesophyll cells of cassava, 7 days after infection by Xam X27 isolate (aldehyde fixed, immunogold labeling). A, Gold label is specifically associated with bacteria (B) and the fibrillar material filling intercellular space (IS); the cell wall (CW) and the contents of the host cell (HC) are devoid of labeling. B, Gold label occurs over the intercellular space (IS) occupied by the fibrillar sheath; labeling is also present over areas (arrows) of the host cell walls (CW). C, Gold labeling is seen over outer layer and cell surface of bacteria growing in an intercellular space of the palisade tissue; the surrounding fibrillar sheath is unlabeled. Labeled wall material (arrows) is shed from the wall. D, Outer layer of this degenerated bacteria in a host vessel is evenly labeled. E, Gold decoration is visible on periphery of the bacteria (B) and on two locations (arrows) in the host cell wall (CW). Intercellular space (IS) and host cell content $(\mathrm{HC})$ are devoid of labeling. F, Portions of the degraded middle lamella of this spongy parenchyma cell are heavily labeled (arrows); labeling is also visible on inner surface of plant cell wall (white arrowheads); gold particles occur over the outer layer of the bacteria (B), but are absent from the fibrillar sheath (FS) filling the intercellular space. Bars $=0.5 \mu \mathrm{m}$. 
of an exoglucanase conjugated to colloidal gold, label also was seen over the primary cell walls and middle lamellae of infected leaves (Fig. 4D). By contrast, no significant labeling was seen over the bacterial extracellular polysaccharides or bacterial cells.

\section{DISCUSSION}

Interaction between Xanthomonas extracellular polysaccharides and plant cell walls during pathogenesis was evaluated by immunocytochemistry. Specificity of B3 MAb for the EPS xanthan of $X$. campestris was assessed by Haaheim and coworkers (1989); they determined that this antibody required a fully acetylated side chain with the pyruvilated mannose as the immunodominant parts. Our BOR9H8 MAb binds to surface-exposed, periodate-sensitive, and heat-, protease-, and lysozyme-resistant molecules that give a ladder-like profile typical of LPS after Western blotting. These features strongly support the suggestion that the specific antigen of this MAb is a component of the $\mathrm{O}$ chain of Xam LPS. BOR9H8 crossreacted with a few pathovars of Xanthomonas whereas other antibodies specific for periodate-sensitive (Wingate et al. 1990) or LPS (Benedict et al. 1990) epitopes are pathovar specific. On the other hand, MAbs reacting with $E$. carotovora subsp. atroseptica LPS cross-react with a Comamonas sp. (Hyman et al. 1995) and two MAbs specific to a periodatesensitive epitope from $P$. syringae reacted with different pathovars (Wingate et al. 1990).

Immunochemical observations reported here confirmed that Xam EPS is a major component of the fibrillar matrix filling intercellular spaces during colonization of leaf tissues, as proposed by Brown et al. (1993) and Boher et al. (1995). The close relationship revealed between the destructured middle lamella and Xam EPS, in conjunction with immunocytolocali-
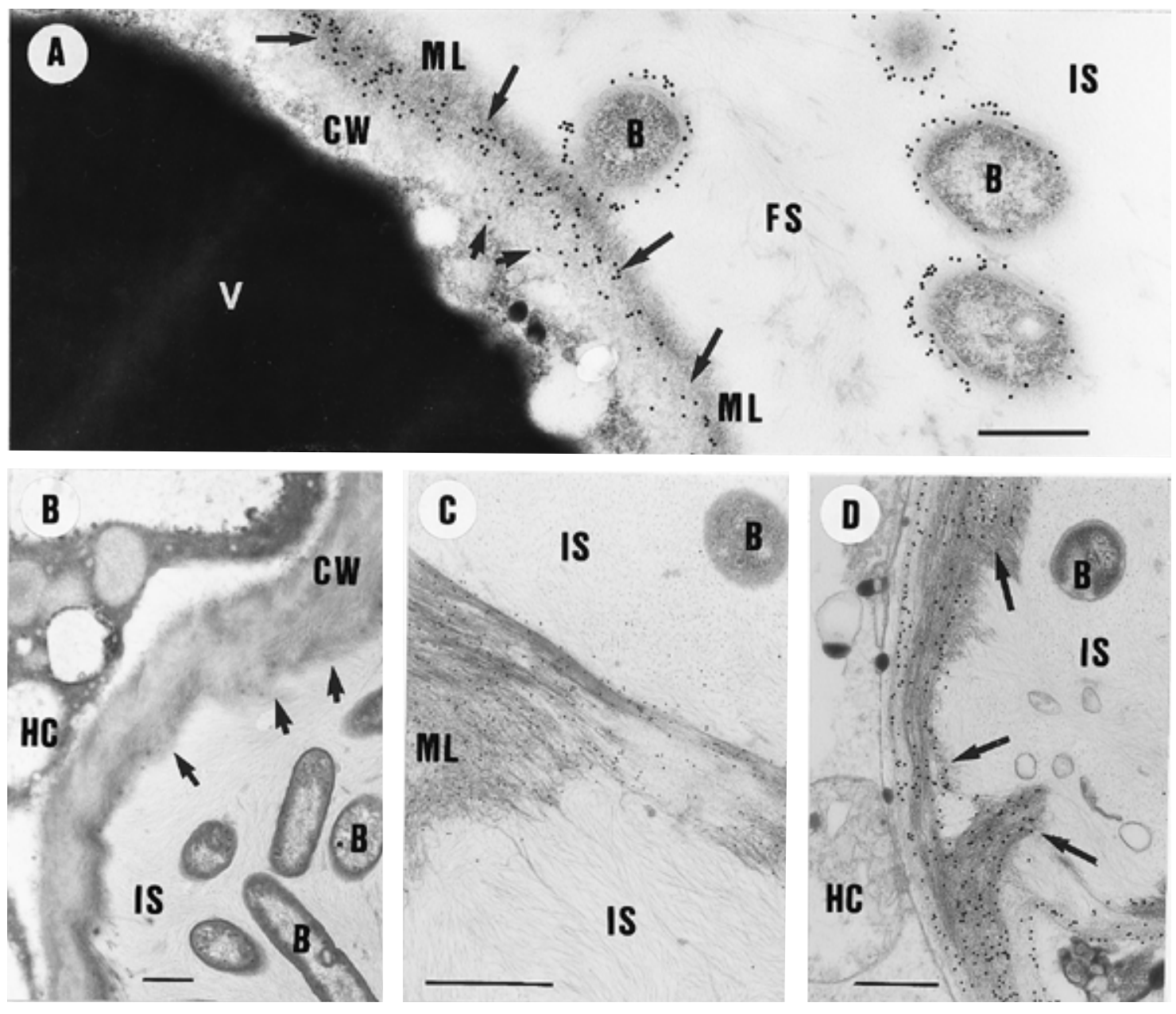

Fig. 4. Imunocytochemical localization of BOR9H8 monoclonal antibody (MAb) epitope in mesophyll tissues of cassava, 7 days after infection by Xam X27 (aldehyde fixed, immunogold labeling) (A), and by Xanthomonas cassavae isolate UPB049 (B). Immunocytochemical localization of pectic epitopes with MAb JIM5 (C) and cytolocalization of $\beta$-1,4-glucans from cellulose with a gold-conjugated exoglucanase (D) in cassava tissues colonized by Xam X27 isolate. A, An even distribution of label (arrows) is seen over the degraded middle lamella (LM) bordering the mesophyll intercellular space (IS). Gold particles also occur over the cell wall (CW, small arrows) and the outer layer of the bacteria (B), but are absent from the fibrillar sheath (FS) filling the intercellular space. The vacuole $(\mathrm{V})$ of the adjacent cell is filled with an electron-dense material. B, After treatment of sections from cassava mesophyll tissues colonized by X. cassavae with BOR9H8 MAb, no labeling occurs over the degraded middle lamella (arrows) and over the bacteria (B) (aldehyde fixed). C, Treatment of sections from cassava mesophyll infected by Xam X27 isolate with the JIM5 MAb probe reveals the presence of numerous gold particles over the altered middle lamella (ML); the fibrillar matrix and the bacteria (B) occupying the intercellular space (IS) are devoid of significant labeling (double fixed). D, In the same tissues as in $\mathbf{C}$, the host cell wall and the degraded middle lamella are evenly labeled by the exoglucanase-gold probe; the bacteria (B) and the fibrillar matrix in intercellular space (IS) do not exhibit any gold labeling (double fixed). Bars $=0.5 \mu \mathrm{m}$. 
zation of xanthan in host cell wall portions, strongly indicates that plant cell wall compounds may, as we previously demonstrated, interfere with EPS during plant cell wall degradation (Boher et al. 1995). Xanthan is known to interact with certain plant gluco- or galactomannans (Sutherland 1993); such molecular binding may contribute to the formation of a gel that may have a striking effect on plant colonization by Xanthomonads.

In the present paper, we report for the first time immunocytological evidence for a close association between bacterial LPS and the degraded host middle lamella during pathogenesis. However, the presence of galacturonic acid in the watersoluble LPS from X. campestris (Volk 1966, 1968) raises the possibility of a common binding epitope for BOR9H8 MAb in both Xam LPS and the degraded middle lamella. Several controls, including the addition of cell wall compounds such as galacturonic acid to the MAb prior to incubation of sections, did not alter the labeling pattern. In addition, no immunodetection of the BOR9H8 epitope was found in the cassava middle lamella lysed during invasion by $X$. cassavae, although pectinolytic activities of both $X$. cassavae and Xam were similar in vitro and in planta (B. Boher, unpublished). These observations suggest that the epitope recognized in the host apoplast by the BOR9H8 MAb is not of plant origin.

Occurrence of the BOR9H8 epitope at a distance from the bacteria indicates that Xam LPS can diffuse in host tissues. Robinson (cited by Hodson et al. 1995) suggested that $X$. campestris LPS may be found in host tissues ahead of the invading organism. Specific binding to and traversing cell walls of clover root hairs by LPS from $R$. trifolii were mentioned by Dazzo et al. (1991). Although this result was obtained by dipping clover roots in a purified solution of Rhizobium LPS, it demonstrated interactions between bacterial and plant polysaccharides. Similarly, $\mathrm{N}$-acetyl galactosamine residues, components of the bacterial cell envelope, were detected in the middle lamella of tomato tissues colonized by the grampositive bacterium C. michiganense (Benhamou 1991). Immunocytolocalizsation of Xam LPS over bacteria and, at distance, in the host middle lamella, while no labeling was apparent in intercellular spaces filled with the bacterial fibrillar matrix, raises the question of how LPS is translocated from bacteria to host cell. In this respect, the two following hypotheses are proposed:

(1) Gram-negative bacteria can liberate cell surface material as blebs, for example, as described for E. amylovora (Hignett 1988). Xam smears treated with BOR9H8 MAb and observed by immunofluorescence microscopy also revealed the presence of fluorescent blebs detached from the cell surface (data not shown); these were also observed after ultrastructural analysis in planta (Fig. 3C). In early interactions, deposition of outer membrane components shed from the bacteria onto cassava cell walls may result from the close contacts that occur at this stage between Xam and cassava leaf cells. Later in infection, when EPS fill the colonized intercellular spaces, the bacteria are separated from this shed outer membrane material.

(2) Heavy BOR9H8 labeling in some areas of the degraded middle lamella, with neighboring extracellular spaces devoid of any labeling, likely did not result only from deposition of shed material. We suggest that LPS may be translocated from the Xam surface to the host cell, and that this translocation may occur via the xanthan fibrillar network. During translocation, interaction between xanthan and LPS may account for masking of the BOR9H8 epitope, explaining why LPS labeling failed at these sites. Contacts between extracellular bacterial polysaccharides and plant pectic components may modify the molecular conformation of the LPS/EPS complex, thus exposing the BOR9H8 epitope during lysis of the middle lamellae. Alteration of pectin by Xam enzymes could provide access to $\mathrm{Ca}^{2+}$, which may bind to bacterial LPS (Galanos and Lüderitz 1975) and cause the LPS to aggregate and accumulate in degraded portions of middle lamellae. LPS accumulation in host wall structures also may result from a lectin-like interaction, as previously described in the cassava/Xam system (Lima et al. 1990).

Observation of reduced pathogenicity expressed by mutants affected in LPS structure in the genus Xanthomonas (Newman et al. 1994; Dow et al. 1995) or Erwinia (Schoonejans et al. 1987) suggested that these compounds may function in pathogenicity. Among more than 1,000 Xam strains isolated from various African cassava-growing countries, we have found only one avirulent isolate (ORST4). This isolate does not cross-react with BOR9H8 and lacks smooth LPS, as attested by absence of ladder-banding profile after electrophoresis (Fig. 1, lane 2). Data presented here and enzyme-linked immunosorbent assays (ELISAs) (B. Boher, unpublished) on 57 strains from various geographical origins did not reveal any correlation between virulence and the presence of BOR9H8 epitope. However, all virulent isolates not reacting in vitro with BOR9H8 MAb became positive in vivo during pathogenesis. This suggests that LPS may be synthesized de novo, or structurally modified during leaf colonization by the pathogen. Similar changes in LPS structure during plant infection also were noted by Osman et al. (1986) with Pseudomonas syringae pv. glycinea and by Kannenberg et al. (1994) with Rhizobium, indicating that expression of LPS epitopes may be associated with bacterial adaptation to the plant environment.

In conclusion, the results presented here confirm cytochemically the association of Xam extracellular polysaccharides with cassava cell walls and middle lamella. Evidence for the LPS BOR9H8 epitope location within degraded plant walls demonstrates that this bacterial polysaccharide closely interacts with host tissues, although the function the released LPS have in the plant/pathogen interaction remains obscure. It would be of interest to investigate the role that Xam LPS may play in the process of wall alteration and elicitation of plant defense, since both pectin oligosaccharides (Ryan and Farmer 1991) and Xanthomonas LPS (Newman et al. 1995) have been shown to induce defense-related gene expression. Reports on the toxicity of Xanthomonas LPS toward animal cells (Volk 1966) raise the question of cytotoxic effects of LPS on plant cells. In this respect, immunolabeling of BOR9H8 epitope in the periplasmic area of mesophyll cells indicates the possibility of contacts between LPS and the host plasma membrane.

\section{MATERIALS AND METHODS}

\section{Bacterial strains.}

The strains used for this study are listed in Table 1. All strains were stored as frozen glycerol stocks and were grown on YPGA medium (5\% yeast extract, $5 \%$ peptone, $5 \%$ glucose, and $15 \%$ agar; Difco, Detroit, MI). 


\section{Plant material and artificial infection.}

In vitro plantlets from the susceptible cultivar Fetonegbodji (originating from Togo) were used. They were rendered virus free by thermotherapy and meristem regeneration and then multiplied in culture flasks (Kartha and Gamborg 1975). After transplanting, plants were maintained in pots containing compost at $27.5 \pm 1{ }^{\circ} \mathrm{C}, 14 / 10 \mathrm{~h}$ light/dark regime (fluorescent, cool white, $50 \mu \mathrm{E} \mathrm{s}^{-1} \mathrm{~m}^{-2}$ ) and $85 \%$ relative humidity. Young, unfolded leaves of 8-week-old plants were infected by depositing a 5 - $\mu$ l drop of bacterial suspension $\left(10^{8} \mathrm{CFU} / \mathrm{ml}\right)$ in a hole made with a cork borer (1.5 $\mathrm{mm}$ in diameter).

Isolates of various Xanthomonas pathovars, including Xam and $X$. cassavae, were assayed for their pathogenicity on cassava leaves according to Verdier et al. (1994).

\section{Antigen preparation, immunization of mice, and production of hybridomas.}

Isolate X27 of Xam was cultured on a nitrogen-deficient liquid medium (Sutherland and Wilkinson 1965). After $48 \mathrm{~h}$ of growth at $30^{\circ} \mathrm{C}$ under agitation, bacterial cells were removed by centrifugation at $25,000 \times g$ for $30 \mathrm{~min}$. Polysaccharides were recovered in the supernatant by precipitation with 2 vols of cold $\left(-40^{\circ} \mathrm{C}\right)$ acetone. After thorough washing with acetone, polysaccharides were dissolved in a small volume of water, dialyzed against distilled water, and lyophilized. This material was used for immunizing mice.

$\mathrm{BALB} / \mathrm{c}$ mice were immunized by intraperitoneal injections three times at 2-week intervals with $100 \mu \mathrm{g}$ of the lyophilized antigen dissolved in $50 \mu \mathrm{l}$ of water. Two hundred and fifty microliters of Freund's incomplete adjuvant was added for the first injection and $250 \mu \mathrm{l}$ of Freund's complete adjuvant for the two following injections. Ten days after the third injection, the titer was determined by ELISA. Lymphocytes from the spleen of an immunized mouse were fused with X63Ag8/653 myeloma cells in $40 \%$ polyethylene glycol and aliquoted to $96-w e l l$ plates. The hybridomas were selected in HAT medium (RPMI 1640, Biowhittaker, Walkersville, MD), $0.3 \%$ glutamine, $0.2 \%$ sodium pyruvate, 2\% HAT (H 0262; Sigma, St. Louis, MO), 20\% fetal calf serum, and $1 \%$ penicillin and streptomycin. Six hundred and fifteen hybridoma supernatants were assayed by indirect ELISA against the antigen. Among six hybridomas selected, BOR9H8, the most reactive on the antigen, was chosen and the culture supernatant was used for this study.

\section{Anti-xanthan antibody.}

Ascitic fluid of hybridomas secreting B3 MAb (IgMk) with specificity against the side chain of xanthan from $X$. campestris (Haaheim et al. 1989) was obtained from L. R. Haaheim (University of Bergen, Bergen, Norway).

\section{LPS extraction, purification, and electrophoresis.}

Bacteria grown $30 \mathrm{~h}$ on YPGA liquid medium were harvested by centrifugation and washed six times with water to exclude EPS. LPS were extracted from the pellet $(6 \mathrm{~g}$ fresh weight) by the hot phenol water method of Westphal and Jann (1965). The crude LPS extract (water phase) was then treated according to the methods given by Barton-Willis et al. (1984). After dialysis against water, the extracts were brought to $1.5 \%$ $\mathrm{NaCl}$ and $1.5 \%$ cetavlon (hexadecyl-trimethylammonium bromide), and stirred at room temperature for $10 \mathrm{~min}$. The mixture was centrifuged at $10,000 \times g$ and $10 \times$ vol of $95 \%$ ethanol was added to the supernatant. After standing one night at $4^{\circ} \mathrm{C}$, the mixture was centrifuged and the resulting precipitate was solubilized in water and dialyzed against water to give $3.5 \mathrm{ml}$ of LPS crude solution. Proteins were digested by proteinase $\mathrm{K}$ (EC 3.4.21.14, Merck, Darmstadt, Germany; $10 \mathrm{mg}$ of final concentration per $\mathrm{ml}$ at $\mathrm{pH} 7$ and $37^{\circ} \mathrm{C}$ for $3 \mathrm{~h}$ ). LPS was submitted to lysozyme digestion (LYS002, Bioprobe, Montreuil, France; $20 \mathrm{mg}$ of final concentration per $\mathrm{ml}$ at $\mathrm{pH}$ 7 and $37^{\circ} \mathrm{C}$ for $2 \mathrm{~h}$ ). Lysates were heated at $100^{\circ} \mathrm{C}$ for $15 \mathrm{~min}$ before electrophoresis.

Electrophoretic separation of 10-ml samples mixed with 10 $\mathrm{ml}$ of lysing buffer containing $2 \%$ sodium dodecyl sulfate (SDS), 4\% 2-mercaptoethanol, 10\% glycerol, $1 \mathrm{M}$ Tris (pH 6.8), and bromphenol blue was performed as described by Laemmli (1970). The $4 \%$ stacking gel and the $12.5 \%$ separating gel did not contain SDS. Preferential staining of LPS on gel was performed according to the Ag-LPS staining procedure described by Hitchcock and Brown (1983). Electrophoresis was done at $70 \mathrm{~mA}$ of constant current with Tris-glycine (pH 8.3) plus $0.1 \%$ SDS buffer for approximately $1 \mathrm{~h}$.

\section{Electroblot transfer and immunodetection.}

LPS was electrophoretically transferred from gel onto a polyvinylidene fluoride membrane (Immobilon-P, Millipore, Bedford, MA) with a Mini Trans-Blot cell (Bio-Rad, Hercules, CA) for $3 \mathrm{~h}$ at $20 \mathrm{~V}$ and $150 \mathrm{~mA}$. Membranes were blocked with $5 \%$ skimmed milk overnight at $4^{\circ} \mathrm{C}$, then incubated $1 \mathrm{~h}$ with BOR9H8 diluted 1/32 at room temperature. After washing, the blots were developed with a goat antimouse IgG antibody (A-3563, Sigma) conjugated to alkaline phosphatase and substrate containing $23 \mathrm{mg}$ of nitro blue tetrazolium (B-5655, Sigma) per ml.

\section{Microscopy.}

Fragments of inoculated leaf tissues (about $2.0 \mathrm{~mm}^{2}$ ) were fixed for $4 \mathrm{~h}$ in $1 \%$ glutaraldehyde, $4 \%$ paraformaldehyde in $0.1 \mathrm{M}$ cacodylate buffer $\mathrm{pH} 7.2$, and dehydrated in graded series of ethanol before embedding in LR White (TAAB, Aldermaston, Reading, UK), according to the company's recommendation. Concurrently, samples were fixed in $2.5 \%$ glutaraldehyde buffered with $0.1 \mathrm{M}$ cacodylate $\mathrm{pH} 7.2$, rinsed in the same buffer, and postfixed for $1 \mathrm{~h}$ in $1 \%$ osmium tetroxide. They were dehydrated in a graded series of ethanol followed by propylene oxide, and embedded in Epon 812 (TAAB). Samples were semi-thin $(1.5 \mathrm{~mm})$ or thin $(90 \mathrm{~nm})$ sectioned with a diamond knife on an Ultracut $\mathrm{E}$ microtome (Reichert, Vienna). For periodate oxidation, sections were treated according to Keen and Legrand (1980).

Semi-thin sections were mounted in phosphate-buffered glycerol and examined with a light microscope (Leitz Diaplan, Wetzlar, Germany). For fluorescence observation, excitation (450 to $490 \mathrm{~nm}$ ) and barrier (515 nm) filters were used. Thin sections were viewed under a transmission electron microscope operating at $80 \mathrm{kV}$ (Jeol 100EX, LPRC, CIRAD, Montpellier, France).

\section{Immunocytolocalization of EPS and LPS.}

For immunolocalization, all solutions were prepared in 20 $\mathrm{mM}$ phosphate-buffered saline $(\mathrm{pH} 7.2)$ with $0.5 \%$ bovine serum albumin (BSA) and $0.05 \%$ Tween 20 (TBST). After blocking in $2.5 \%$ BSA (20 min at room temperature) sections 
were incubated on a drop of the primary antibody (ascitic fluid) diluted in TBST (BOR9H8 1/40 for semi-thin and 1/2 for thin sections; B3 1/400 for semi-thin and 1/100 for thin sections). Incubation time was $30 \mathrm{~min}$ at $37^{\circ} \mathrm{C}$ for immunofluorescence on semi-thin sections and $14 \mathrm{~h}$ at $4^{\circ} \mathrm{C}$ for immunogold localization on thin sections. After three washes in TBST, sections were incubated for $30 \mathrm{~min}$ at $37^{\circ} \mathrm{C}$ in fluorescein or gold-labeled goat anti-mouse antibodies (F5262, Sigma; GAM-15, Biocell, Cardiff, UK) diluted 1/20 in TBST.

Specificity of labeling was assessed through the following control experiments performed on sections from healthy and infected leaves: (i) incubation with the B3 or BOR9H8 MAbs previously adsorbed with the corresponding antigen, xanthan, and purified LPS, respectively; (ii) incubation with BOR9H8 MAb previously adsorbed with commercial plant cell wall compounds, including galacturonic acids and $\beta$-1,4-glucans; (iii) incubation with preimmune mouse serum instead of the primary antiserum; and (iv) omission of the primary antibody incubation step.

\section{Immunocytolocalization of pectin epitopes.}

A monoclonal antibody (JIM5, kindly provided by K. Roberts, J. Innes Center, Norwich, England) raised against unesterified epitopes of pectin was used to visualize galacturonic acid-containing molecules. Immunogold localization of pectin was performed as previously described by Knox et al. (1990). Briefly, sections were first incubated on a drop of primary antibodies for $2 \mathrm{~h}$ at $37^{\circ} \mathrm{C}$ and then on a drop of gold-labeled goat anti-rat antibodies (GAT 15, Biocell) for $30 \mathrm{~min}$ at $37^{\circ} \mathrm{C}$.

Specificity of labeling was assessed through the following control experiments performed on sections from healthy and infected roots: (i) incubation with the antiserum previously adsorbed with polygalacturonic acid; (ii) incubation with preimmune mouse serum instead of the primary antiserum; and (iii) omission of the primary antibody incubation step.

\section{Cytolocalization of $\beta$-1,4-glucans with an exoglucanase-gold probe.}

$\beta$-1,4-glucans were localized with a purified exoglucanase kindly provided by C. Breuil (University of British Columbia, Vancouver, Canada). This enzyme was complexed to gold at $\mathrm{pH} 9$ according to the methodology described by Benhamou et al. (1987). Labeling of sections was performed for $30 \mathrm{~min}$ at $25^{\circ} \mathrm{C}$ on a drop of the probe $(\mathrm{pH}$ 6.5) before rinsing and staining. Specificity of labeling was assessed by incubating sections with the gold-complexed protein saturated with an excess of $\beta$-1,4-glucans from barley.

\section{ACKNOWLEDGMENTS}

We acknowledge J. Mansfield (Wye College, University of London, UK) and K. Mendgen (University of Konstanz, Germany) for their helpful comments. C. Breuil (University of British Columbia) and K. Roberts (J. Innes Center) are also acknowledged for kindly providing the purified exoglucanase and JIM5 anti-pectin antibody, respectively. We wish to thank J. C. Laurent (BioEnvirotech, Marseille, France) for advising in monoclonal antibodies preparation.

\section{LITERATURE CITED}

Barton-Willis, P. A., Wang, C., Holliday, M. J., Long, M. R., and Keen, N. T. 1984. Purification and composition of lipopolysaccharides from Pseudomonas syringae pv. glycinea. Physiol. Plant Pathol. 25:387-
398

Benedict, A. A., Alvarez, A. A., and Pollard, L. M. 1990. Pathovar specific antigens of Xanthomonas campestris pv. begoniae and X. campestris pv. pelargonii detected with monoclonal antibodies. Appl. Environ. Microbiol. 56:572-524.

Benhamou, N. 1991. Cell surface interactions between tomato and Clavibacter michiganense subsp. michiganense: Localization of some polysaccharides and hydroxyproline-rich glycoproteins in infected host leaf tissues. Physiol. Mol. Plant Pathol. 38:15-38.

Benhamou, N., Chamberland, H., Ouellette, G. B., and Pauzé, F. J. 1987. Ultrastructural localization of $\beta-(1-4)$ glucans in two pathogenic fungi and their host tissues by means of an exoglucanase-gold complex. Can. J. Microbiol. 33:405-417.

Boher, B., Brown, I., Nicole, M., Kpémoua, K., Verdier, V., Bonas, U., Daniel, J. F., Geiger, J. P., and Mansfield, J. 1996. Histology and cytochemistry of interactions between plants and Xanthomonads. Pages 193-210 in: Histology, Ultrastructure and Molecular Cytology of Plant-Microorganism Interactions. M. Nicole and V. GianinazziPearson, eds. Kluver Academic Pub., Dordrecht, the Netherlands.

Boher, B., Kpémoua, K., Nicole, M., Luisetti, J., and Geiger, J. P. 1995. Ultrastructure of interactions between cassava and Xanthomonas campestris pv. manihotis: Cytochemistry of cellulose and pectin degradation in a susceptible cultivar. Phytopathology 85:777-788.

Brown, I., Mansfield, J., and Bonas, U. 1995. hrp genes in Xanthomonas campestris pv. vesicatoria determine ability to suppress papilla deposition in pepper mesophyll cells. Mol. Plant-Microbe Interact. 8:825836.

Brown, I., Mansfield, J., Irlam, I., Conrads-Strauch, J., and Bonas, U. 1993. Ultrastructure of interactions between Xanthomonas campestris pv. vesicatoria and pepper, including immunocytochemical localization of extracellular polysaccharides and the AvrBs3 protein. Mol. Plant-Microbe Interact. 6:376-386.

Dazzo, F. B., Truchet, G. L., Hollingsworth, R. I., Hrabak, E. M., Pankratz, H. S., Philip-Hollingsworth, S., Salzwedel, J. L., Chapman, K., Appenzeller, L., Squartini, A., Gerhold, D., and Orgambide, G. 1991. Rhizobium lipopolysaccharide modulates infection thread development in white clover root hairs. J. Bacteriol. 173:5371-5384.

Denny, T. 1995. Involvement of bacterial exopolysaccharides in plant pathogenesis. Annu. Rev. Phytopathol. 33:173-197.

Dow, J. M., Osbourn, A. E., Greer-Wilson, T. J., and Daniels, M. J. 1995. A locus determining pathogenicity of Xanthomonas campestris is involved in lipopolysaccharide biosynthesis. Mol. Plant-Microbe Interact. 8:768-777.

Duijff, B. J., Gianinazzi-Pearson, V., and Lemanceau, P. 1997. Involvement of the outer membrane lipopolysaccharides in the endophytic colonization of tomato root by biocontrol Pseudomonas fluorescens strain WC417r. New Phytol. 135:325-334.

Galanos, C., and Lüderitz, O. 1975. Electrodialysis of lipopolysaccharides and their conversion to uniform salt forms. Eur. J. Biochem. 54: 603-610.

Haaheim, L. R., Kleppe, G., and Sutherland, I. W. 1989. Monoclonal antibodies reacting with the exopolysaccharide xanthan from Xanthomonas campestris. J. Gen. Microbiol. 135:605-612.

Hendrick, C. A., and Sequeira, L. 1984. Lipopolysaccharides-defective mutants of the wilt pathogen Pseudomonas solanacearum. Appl. Environ. Microbiol. 48:94-101.

Hignett, R. C. 1988. Effect of growth conditions on the surface structures and extracellular products of virulent and avirulent forms of $\mathrm{Er}$ winia amylovora. Physiol. Mol. Plant Pathol. 32:387-394.

Hitchcock, P., and Brown, T. M. 1983. Morphological heterogeneity among Salmonella lipopolysaccharide chemotypes in silver-stained polyacrylamide gels. J. Bacteriol. 154:269-277.

Hodson, A., Smith, A. R. W., and Hignett, R. C. 1995. Characterization of outer membrane preparation of Pseudomonas syringae pv. morsprunorum and its biological activity in planta. Physiol. Mol. Plant Pathol. 47:159-172.

Hyman, L. J., Wallace, A., Lopez, M. M., Cambra, M., Gorris, M. T., and Pérombelon, M. C. M. 1995. Characterization of monoclonal antibodies against Erwinia carotovora subsp. atroseptica serogroup I: Specificity and epitope analysis. J. Appl. Bacteriol. 78:437-444.

Kannenberg, E. L., Perotto, S., Biancotto, V., Rathbun, E. A., and Brewin, J. 1994. Lipopolysaccharide epitope expression of Rhizobium bacterioids as revealed by in situ immunolabelling of pea roots. J. Bacteriol. 176:2021-2032. 
Kartha, K. K., and Gamborg, O. L. 1975. Elimination of cassava mosaic disease by meristem culture. Phytopathology 65:826-828.

Keen, N. T., and Legrand, M. 1980. Surface glycoproteins: Evidence that they may function as race specific phytoalexin elicitor in Phytophthora megasperma f. sp. glycinea. Physiol. Plant Pathol. 17:175192.

Knox, J. P., Linstead, P. J., King, J., Cooper, C., and Roberts, K. 1990. Pectin esterification is spatially regulated both within cell walls and between developing tissues of root apices. Planta 181:512-521.

Laemmli, V. K. 1970. Cleavage of structural proteins during the assembly of the head of bacteriophage T4. Nature 227:680-685.

Leeman, M., Van Pelt, J. A., Den Ouden, F. M., Heinsbroek, M., Bakker, P. A. H. M., and Schippers, B. 1995. Induction of systemic resistance against Fusarium wilt of radish by lipopolysaccharides of Pseudomonas fluorescens. Phytopathology 85:1021-1027.

Leigh, J. A., and Coplin, D. L. 1992. Exopolysaccharides in plantbacterial interaction. Annu. Rev. Microbiol. 46:307-346.

Lima, M. I. P. M., Romeiro, R. S., and Muchovej, J. J. 1990. Cassava agglutination factor against Xanthomonas campestris pv. manihotis. Fitopatol. Bras. 15:48-52.

Mazzuchi, U., Bazzi, C., and Pupillo, P. 1979. The inhibition of susceptible and hypersensitive reactions by protein-lipopolysaccharide complexes from phytopathogenic Pseudomonads: Relationship to polysaccharide antigenic determinants. Physiol. Plant Pathol. 14:19-30.

Mazzuchi, U., and Pupillo, P. 1976. Prevention of confluent hypersensitive necrosis in tobacco leaves by a bacterial protein-lipopolysaccharide complex. Physiol. Plant Pathol. 9:101-112.

Newman, M.-A., Conrads-Strauch, J., Scofield, G., Daniels, M. J., and Dow, M. J. 1994. Defense-related gene induction in Brassica campestris in response to defined mutants of Xanthomonas campestris with altered pathogenicity. Mol. Plant-Microbe Interact. 7:553-563.

Newman, M.-A., Daniels, M. J., and Dow, J. M. 1995. Lipopolysaccharide from Xanthomonas campestris induces defense-related gene expression in Brassica campestris. Mol. Plant-Microbe Interact. 8:778-780.

Ojanen, T., Helander, I. M., Haahtela, K., Korhonen, T. K., and Laakso, T. 1993. Outer membrane proteins and lipopolysaccharides in pathovars of Xanthomonas campestris. Appl. Environ. Microbiol. 59:41434151.

Osman, S. F., Fett, W. F., and Fishman, M. L. 1986. Exopolysaccharides of the phytopathogen Pseudomonas syringae pv. glycinea. J. Bacteriol. 166:66-71.

Ovod, V., Ashorn, P., Yakovleva, L., and Krohn, K. 1995. Classification of Pseudomonas syringae with monoclonal antibodies against the core and O-side chains of the lipopolysaccharide. Phytopathology 85: 226-232.

Ryan, C. A., and Farmer, E. E. 1991. Oligosaccharides signals in plants: A current assessment. Annu. Rev. Plant Physiol. Mol. Biol. 42:651-674.
Schoonejans, E., Expert, D., and Toussaint, A. 1987. Characterization and virulence properties of Erwinia chrysanthemi lipopolysaccharidedefective, fEC2-resistant mutants. J. Bacteriol. 169:4011-4017.

Schouten, H. J. 1989. A possible role in pathogenesis for the swelling of extracellular slime of Erwinia amylovora at increasing water potential. Neth. J. Plant Pathol. 95(suppl. 1):169-174.

Siverio, F., Cambra, M., Gorris, M. T., Corzo, J., and Lopez, M. M 1993. Lipopolysaccharides as determinants of serological variability in Pseudomonas corrugata. Appl. Environ. Microbiol. 59:1805-1812.

Sutherland, I. W. 1993. Xanthan. Pages 363-388 in: Xanthomonads. J. C. Swings and E. L. Civerolo, eds. Chapman \& Hall, London.

Sutherland, I. W., and Wilkinson, J. F. 1965. Depolymerases for bacterial exopolysaccharides obtained from phage-infected bacterial. J. Gen. Microbiol. 39:373-383

Van Alfen, N. K., McMillan, B. D., and Wang, Y. 1987. Properties of the extracellular polysaccharides of Clavibacter michiganense subsp. in sidiosum that may affect pathogenesis. Phytopathology 77:501-505.

Verdier, V., Boher, B., Maraite, H., and Geiger, J. P. 1994. Pathological and molecular characterization of Xanthomonas campestris strains causing diseases of cassava (Manihot esculenta). Appl. Environ. Microbiol. 60:4478-4486.

Vidhyasekaran, P., Alvenda, M. E., and Mew, T. W. 1989. Physiological changes in rice seedlings induced by extracellular polysaccharide produced by Xanthomonas campestris pv. oryzae. Physiol. Mol. Plant Pathol. 35:391-402.

Volk, W. A. 1966. Cell wall lipopolysaccharides from Xanthomonas species. J. Bacteriol. 91:39-42.

Volk, W. A. 1968. Quantitative assay of polysaccharide components obtained from cell wall lipopolysaccharides of Xanthomonas species. J. Bacteriol. 95:980-982.

Watabe, M., Yamagushi, M., Kitamura, S., and Horino, O. 1993. Immunohistochemical studies on localization of the extracellular polysaccharide produced by Xanthomonas oryzae pv. oryzae in infected rice leaves. Can. J. Microbiol. 39:1120-1126.

Westphal, O., and Jann, K. 1965. Bacterial lipopolysaccharides. Extraction with phenol water and further applications procedure. Methods Carbohydr. Chem. 5:83-91.

Whatley, M. H., Bodwin, J. S., Lippincott, B. B., and Lippincott, J. A. 1976. Role of Agrobacterium cell envelope lipopolysaccharide in infection site attachment. Infect. Immun. 13:1080-1083.

Wingate, V. P. M., Norman, P. M., and Lamb, C. J. 1990. Analysis of the cell surface of Pseudomonas syringae pv. glycinea with monoclonal antibodies. Mol. Plant-Microbe Interact. 3:408-416.

Zamze, S. E., Smith, A. R. W., and Hignett, R. C. 1985. Composition of lipopolysaccharide from strains of Pseudomonas syringae pv. morsprunorum of differing host specificity and virulence. J. Gen. Microbiol. 131:1941-1950. 